\title{
In memory of Geoffrey Burnstock (1929-2020)
}

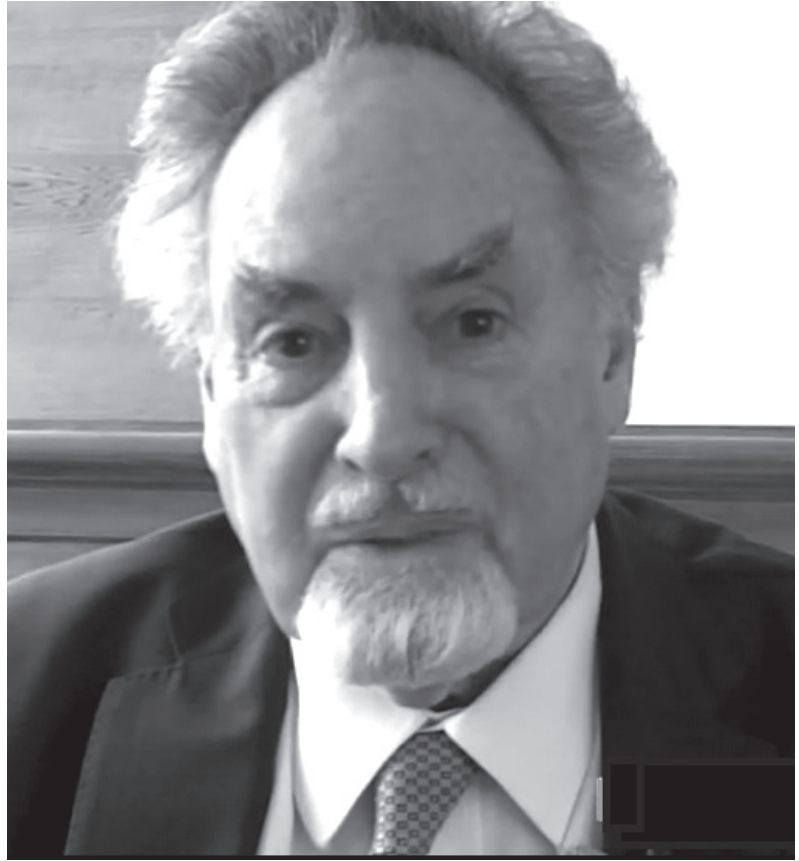

Geoffrey Burnstock (1929-2020)

On June 2 our scientific community was struck with unexpected sad news. Geoffrey Burnstock, one of the greatest biochemists and physiologists of our times passed away at the age of 91. Professor Burnstock (or Geoff as he was called by friends and coworkers) was widely recognized for his discovery of purinergic transmission in the peripheral nervous system and for leading the subsequent efforts to uncover the entire network of signaling pathways triggered by extracellular nucleotides and nucleosides. Although this area of biochemistry appears somewhat elusive to non-specialists, the practical aspects of his discoveries are well known to almost everyone on the planet, even though they might not be aware of it. One of the most widely prescribed drugs today, blood thinner clopidogrel (Plavix) antagonizes the P2Y12 receptor in platelets, reduces blood coagulation and prevents coronary heart disease and stroke. It is featured on the WHO List of Essential Medicines. Every coffee drinker has experienced central and peripheral effects of purinergic modulation. Caffeine is a naturally occurring antagonist of the A2a receptor in the ventrolateral proptic area and it exerts it antisleep effect by blocking GABA transmission in the tuberomammilary nucleus. Caffeine also affects the heart rate, breathing and bowel movements. Interestingly, gut was the region where Geoff made his first observations as scientist. In the late $1950 \mathrm{~s}$, during his $\mathrm{PhD}$ at King's College in London, he became puzzled by the difference in regulation of peristaltic movements in different species of fish (some omnivorous species eat and digest all the time, while predators can survive long periods without food). After completing his $\mathrm{PhD}$, he learnt the essential electrophysiological methods at National Institute for Medical Research, then had a brief stint at the Oxford University. This was the time when he mastered the technique of recording from isolated patches of guinea pig gut smooth muscle by sucrose gap method. It allowed him to study ex vivo the mechanisms of autonomic innervation of the intestine. His most influential discoveries were done during the appointment at the University of Melbourne (19591975). For the first several years he attempted to identify the specific transmitter responsible for gut contraction. After exhausting all possible pharmacological approaches aimed at targeting known neurotransmitter systems, he came to the conclusion that a novel transmitter was involved. He then proceeded to break two dogmas in a series of papers published between 1970 and 1976 (Burnstock et al., 1970; Burnstock et al., 1972a; Burnstock et al., 1972b; Burnstock, 1976). First, he suggested that no less than two neurotransmitters are simultaneously released at the peripheral synapse. He first termed this phenomenon "NANC" (non-adrenergic, non-cholinergic transmission). This idea stood in striking contrast to the Dale's principle ("one synapse, one transmitter") that dominated neuroscience until the 1980s. But that one travesty wasn't enough. He suggested that no other molecule but ATP, acting via a specific membrane receptor, was responsible for this extracellular effect. It was known since the works of Szent-Györgi in 1929 that ATP might exert some effect when injected into cardiac muscle, but the idea of a "purinergic" receptor was still too radical for the community to accept. ATP was considered a strictly intracellular molecule, and its presence in the extracellular space would only be possible under pathological conditions. It took Burnstock over 20 years to unequivocally prove his point. Between 1993 and 1995, several papers finally reported cloning of specific rat and human receptors for ATP. Despite difficulties, those 20 years were prolific for Geoff and his steadily growing group of followers. By early '90s, biochemical and pharmacological studies had defined two large families of purinergic receptors: P1 for adenosine and P2 for ATP. P2 were further subdivided into ligand gated, channel forming P2X and G-protein coupled receptors of the P2Y subfamily (Fredholm et al., 1997). All these pharmacological and biochemical findings were confirmed by subsequent cloning of specific receptors. Also, purinergic transmission was described for numerous other organs, tissues and cell types (Abbracchio \& Burnstock, 1998; Burnstock, 2007; Burnstock, 2017). It is beyond the reach of this brief note to list them all. The world of NANC transmitters also expanded to include not only classical neurotransmitters but also a whole range of signaling peptides.

In 1975, Burnstock returned to London and assumed a position as the head of the Department of Anatomy and Embryology at University College London. He stepped down in 1997 and then ran the Autonomic Neuroscience Research Institute until 2004. After that 
he remained active in the scientific community, writing review papers, giving talks and working as Chief Editor of the journal Purinergic Signalling. In 2017 he moved to Melbourne University, assuming the position of honorary professor.

Geoff's life wasn't exclusively devoted to science. However even his free time and relax were full of creativity. He was a talented sculptor, the author of collection of pieces, now at display at UCL (https://www.ucl. ac.uk/ani/prof-GB.htm). Geoff was survived by Nomi, his wife of 61 years, three daughters and seven grandchildren.

\section{Personal recollection from Jolanta Barańska}

In 1999 my team at Laboratory of Signals Transduction, Nencki Institute, started investigating the effect of extracellularly applied nucleotides on the ERK kinase activity and proliferation of glioma C6 cells. We had previously identified three subtypes of membrane receptors for these compounds. Two of them (P2Y1 and P2Y2) are coupled to phospholipase C, and calcium release (Sabala et al., 2001), the third receptor (P2Y12) is negatively coupled to adenyl cyclase via Gi protein (Czajkowski et al., 2002). Our initial observations indicated that all of three receptors could be involved in the regulation of proliferation, despite differences in downstream signaling pathways. To our uttermost surprise, in 2001 a paper emerged that showed complete neglect of the P2Y1 receptor in a seemingly identical model of glioma C6 (Claes et al., 2001). According to authors, only P2Y12 was responsible for the ERK effect. Luckily, the purinergic signaling community is a closely bound group of researchers, and no conflict followed. Instead, both labs closely reexamined the protocols and we discovered that differences of culture medium composition led to massive shifts in receptor expression (Barańska et al., 2004; Czajkowski et al., 2004). These findings were announced in 2004 at the FEBS Congress in Warsaw. This was where we all first met Geoffrey Burnstock in person. Geoff was extremely happy and proud to see $\mathrm{PhD}$ students from both labs delivering in depth reports on our joint investigation. He himself presented an overview of purinergic signaling research that started in the early 70's. We then capped the evening with a dinner at one of Warsaw nicest restaurants. On another evening during FEBS Congress I had the pleasure to host a dinner for Geoff and other "purinergic" friends. Since then we co-redacted a number of publications, and that year we launched a journal dedicated solely to purinergic signaling.

It is impossible to convey in such a brief note the sheer class of Geoffrey as a person. Each conversation or email exchange was an intellectual feast. Geoffs wit and sense of humor were legendary in our circles. The tone and volume of his laughter was unmistakable, and so was his most characteristic feature: the wild, bushy eyebrows. He will be missed by at least three generations of scientists. The story of his life sets a stellar example for the generations to follow.

\section{REFERENCES}

Abbracchio MP, Burnstock G (1998) Purinergic signalling: Pathophysiological roles. Jap J Pharmacol 78: 113-145. https://doi.org/10.1254/ jip. 78.113

Barańska J, Czajkowski R, Sabała P (2004) Cross-talks between nucleotide receptor-induced signaling pathways in serum-deprived and non-starved glioma C6 cells. Adv Ensyme Regul 44: 219-232. https://doi.org/10.1016/j.advenzreg.2003.11.001

Burnstock G (1976) Purinergic receptors. I Theor Biol 62: 491-503. https://doi.org/10.1016/0022-5193(76)90133-8

Burnstock G (2007) Physiology and pathophysiology of purinergic neurotransmission. Physiol Rev 87: 659-797. https://doi.org/10.1152/ physrev.00043.2006

Burnstock G (2017) Purinergic Signalling: Therapeutic Developments. Front Pharmacol 8: 661. https://doi.org/10.3389/fphar.2017.00661

Burnstock G, Dumsday B, Smythe A (1972a) Atropine resistant excitation of the urinary bladder: the possibility of transmission via nerves releasing a purine nucleotide. Br J Pharmacol 44: 451-461. https:// doi.org/10.1111/j.1476-5381.1972.tb07283.x

Burnstock G, Satchell DG, Smythe A (1972b) A comparison of the excitatory and inhibitory effects of non-adrenergic, non-cholinergic nerve stimulation and exogenously applied ATP on a variety of smooth muscle preparations from different vertebrate species. $\mathrm{Br}$ J Pharmacol 46: 234-242. https://doi.org/10.1111/j.1476-5381.1972. tb06868.x

Burnstock G, Campbell G, Satchell D, Smythe A (1970) Evidence that adenosine triphosphate or a related nucleotide is the transmitter substance released by non-adrenergic inhibitory nerves in the gut. $\mathrm{Br}$ J Pharmacol 40: 668-688. https://doi.org/10.1111/j.1476-5381.1970. tb10646.x

Claes P, Grobben B, Van Kolen K, Roymans D, Slegers H (2001) P2Y(AC)(-)-receptor agonists enhance the proliferation of rat C6 glioma cells through activation of the $\mathrm{p} 42 / 44$ mitogen-activated protein kinase. Br J Pharmacol 134: 402-408. https://doi.org/10.1038/ sj.bjp.0704271

Czajkowski R, Lei L, Sabała P, Barańska J (2002) ADP-evoked phospholipase $\mathrm{C}$ stimulation and adenylyl cyclase inhibition in glioma C6 cells occur through two distinct nucleotide receptors, P2Y(1) and P2Y(12). FEBS Lett 513: 179-183. https://doi.org/10.1016/s00145793(02)02255-X

Czajkowski R, Banachewicz W, Ilnytska O, Drobot LB, Baranska J (2004) Differential effects of P2Y1 and P2Y12 nucleotide receptors on ERK1/ERK2 and phosphatidylinositol 3-kinase signalling and cell proliferation in serum-deprived and nonstarved glioma C6 cells. Br J Pharmacol 141: 497-507. https://doi.org/10.1038/sj.bjp.0705639

Fredholm BB, Abbracchio MP, Burnstock G, Dubyak GR, Harden TK, Jacobson KA, Schwabe U, Williams M (1997) Towards a revised nomenclature for $\mathrm{P} 1$ and $\mathrm{P} 2$ receptors. Trends Pharmacol Sci 18: 79-82. https://doi.org/10.1016/s0165-6147(96)01038-3

Sabala P, Czajkowski R, Przybyłek K, Kalita K, Kaczmarek L, Barańska J (2001) Two subtypes of $G$ protein-coupled nucleotide receptors, $\mathrm{P} 2 \mathrm{Y}(1)$ and $\mathrm{P} 2 \mathrm{Y}(2)$ are involved in calcium signalling in glioma C6 cells. Br J Pharmacol 132: 393-402. https:/\%doi. org/10.1038/sj.bjp.0703843 